$\underline{\text { Original Article }}$

\title{
EVALUATION OF INVOLVEMENT OF NEURO-CHEMICAL MECHANISM IN VALERIANA WALLICHII INDUCED ANTIDEPRESSANT EFFECT IN MICE
}

\author{
HARSAHAY MEENA*, V. K. JOSHI, MADHU BALA \\ Defence Institute of Bio-Energy Research (DIBER) DRDO, Goraparao, Haldwani 263139, Dist. Nainital, Uttarakhand (India) \\ Email: harsahayudps@gmail.com
}

Received: 23 Dec 2020, Revised and Accepted: 02 Mar 2021

\section{ABSTRACT}

Objective: Valeriana (V) wallichii DC is found among the ground flora of Himalayan regions and used as herbal medicine for CNS disorders in Indian systems of medicine. In the study, aimed to investigation of involvement of neuro-chemical-systems in $V$. wallichii induced antidepressant effects in mice.

Methods: The antidepressant activity of aqueous alcoholic extracts of $V$. wallichii was measured by using Forced Swim Test and Tail Suspension Test in mice, whereas locomotor activity was observed by Actophotometer. Involvement of adrenergic, dopaminergic and serotonergic receptors in V. wallichii induced antidepressant effects in mice were also observed.

Results: Sub-acute administration of $V$. wallichii in mice showed significant $(\mathrm{P}<0.05)$ increase in the antidepressant activity similar to the Imipramine, but did not show at lower doses in FST. Whereas, pretreatment of adrenergic receptor antagonist, dopaminergic receptor antagonist and serotonin synthesis inhibitor prevented $V$. wallichii induce anti-depressant effect in mice. Lower doses of hydoalcoholic extract of $V$. wallichii did not interfering the locomotor activity in mice during the sub-acute administration, but at a higher dose significantly $(\mathrm{P}<0.05)$ decreases the locomotor activity.

Conclusion: Hence, it is concluded that the antidepressant effect of $V$. wallichii in mice may mediate via adrenergic, dopaminergic and serotonergic systems.

Keywords: Adrenergic, Antidepressant, Dopaminergic, Serotonergic Systems and V. wallichii

(C) 2021 The Authors. Published by Innovare Academic Sciences Pvt Ltd. This is an open access article under the CC BY license (https://creativecommons.org/licenses/by/4.0/] DOI: https://dx.doi.org/10.22159/ijpps.2021v13i5.40615. Journal homepage: https://innovareacademics.in/journals/index.php/ijpps.

\section{INTRODUCTION}

Valeriana (V.) wallichii DC (synonym V. jatamansi; family Valerianaceae), commonly called the Indian valerian, is found among the ground flora of Himalayan regions $(1500-3000 \mathrm{~m})[1,2]$. It is used as a substitute of European $V$. officinalis and also as an ingredient of many herbal medicines in Indian systems of medicine [3]. V. wallichii is used in the treatment of epilepsy, skin disease, hysteria, insanity, cholrea, shell shock, neurosis, snake poisoning, ulcers, asthma, jaundice etc $[1,4-6]$. It is also used as a stimulant, diuretic, anti-spasmodic and antioxidant $[4,7,8]$. The roots/rhizomes of the several species of $V$. wallichii are used as a sleep aid, mild sedative, neuroprotective, anticonvulsant and antistress activities [9-13]. Subhan et al., (2009) [14] have also been reported that the terpenoid content of $V$. wallichii extracts has antidepressant response. The major active principles of $V$. wallichii are valpotriates, dihydrovaltrate, isovalerianate, 6-methylapigenin hesperidins and sesquiterpenoids [5, 15-17]. Thus, aimed of the study was to evaluate involvement of neurochemical receptors in $V$. wallichii induced antidepressant effects.

\section{MATERIALS AND METHODS}

Biological material

The specimens of $V$. wallichii were collected from the region of Bin Block $\left(29.6154^{\circ} \mathrm{N} 80.3199^{\circ} \mathrm{E}\right)$, district Pithoragarh, Uttarakhand (India). Specimens of the plant have been identified in house and matched with the plant samples, which has cultivated in herbal garden of the Institute at field station Pithoragarh. Rhizomes/root parts of $V$. wallichii were dried at $40{ }^{\circ} \mathrm{C}$ temperature in oven to prepare fine powder with the help of mechanical grinder. The freshly prepared dried powder of plant material was subjected to overnight in $20 \%$ ethanolic solution over a period of $48 \mathrm{~h}$ for cold extraction. The extract was concentrated to dryness on a rotary evaporator at $40{ }^{\circ} \mathrm{C}$ to yield a brown dry mass. The final yield was recorded $13.5 \%(\mathrm{w} / \mathrm{w})$. The samples were stored in an airtight container at $(-) 4^{\circ} \mathrm{C}$ for further use. The sample was suspended in 5 $\%$ Tween 80 solution just before administration in mice.

\section{Chemicals}

Chemicals Ethanol and Tween 80 were purchased from E. Merck and Imipramine hydrochloride, p-Chlorophenylalanine (p-CPA) Haloperidol and Prazosin were purchased from Sigma-Aldrich USA.

Animals

Swiss albino male mice (20-25 g body weight, age $10-12 \mathrm{w}$ ) were selected from the Experimental Animal House of the Institute. They were kept in the polycarbonate plastic cages under standard management conditions (Temperature: $22 \pm 3{ }^{\circ} \mathrm{C}$, Relative Humidity50-70\%, and $12 \mathrm{~h} / 12 \mathrm{~h}$ dark/light cycle). The animals had ad libitum access to food and drinking water. All procedures in the present study were carried out under strict compliance of approved directions of CPCSEA (No.1306/c/09/CPCSEA/IAEC/06), Ministry of Environment and Forest, Government of India, New Dehli. The experiments were conducted according to protocols given below.

Acute toxicity study

Fine and uniform suspension of $V$. wallichii was prepared in $5 \%$ Tween 80 solution and administered at different doses viz 30,125 500 and $2000 \mathrm{mg} / \mathrm{kg}$ body weight orally to different groups of mice for acute toxicity. An acute toxicity study was carried out according to the OECD Guideline (423) [18] and animals were observed for 14 $\mathrm{d}$ for any toxic symptoms.

\section{Antidepressant activity by Forced Swim Test (FST)}

The Forced Swim Test (FST) is the most widely used as a pharmacological model for assessing antidepressant activity [19]. The FST was conducted with some modification. Mice were individually forced to swim in an acrylic plastic water pool $25 \mathrm{~cm}$ height $\mathrm{x} 12 \mathrm{~cm}$ diameter) filled $15 \mathrm{~cm}$ water, maintained at $28 \pm 1{ }^{\circ} \mathrm{C}$ temperature and the total immobility time of mice was measured for assessing anti-depressant effect. Similar method was used by Brocardo et al. (2008) [20] and Rosa et al. (2008) [21] and found that classical antidepressant drugs reduces the immobility time of mice. A mouse was considered to be immobile when it remained 
floating or motionless more than $7 \mathrm{~s}$ in the water without struggling, making only minimum movement of its limb necessary to keep its head above the water. The absence of hind leg movement was recorded as immobility by stopwatch. The mice capable of swimming for $8 \mathrm{~s}$ or more in three successive trials were selected for the study. The selected animals were divided into 12 different groups $(n=6)$ to evaluate the antidepressant activity in the FST and investigate the involvement of possible neurochemical mechanism of $V$. wallichii induced antidepressant effect in mice.

Vehicle (5\% Tween 80, Oral) and Imipramine $(15 \mathrm{mg} / \mathrm{kg}$, IP) were administered in group 1 (control) and 2 (positive control) of mice respectively for 21 successive d. Four doses (20, 50, 125 and 300 $\mathrm{mg} / \mathrm{kg}$ ) of an aqueous alcoholic extract of $V$. wallichii were given to the animals' group no 3, 4, 5 and 6 by the oral route for $21 \mathrm{~d}$. All animals were tested by Forced Swim Test (FST) 30 min post administration of doses for the evaluation of antidepressant activity. Before $24 \mathrm{~h}$ of experiment, mice were placed in the water pool for 15 min and removed to dry in a heated enclosure $\left(32{ }^{\circ} \mathrm{C}\right)$ before returning to their home cages. During experiments, animals were placed in the water pool and total duration of immobility was measured for next $5 \mathrm{~min}$.

To investigate the involvement of possible adrenergic neurochemical mechanism of $V$. wallichii induced antidepressant effect in mice, $45 \mathrm{~min}$ post administration of adrenergic antagonist Prazosin (1 mg/kg, IP); vehicle (5\% Tween 80 solution, oral) and $V$. wallichii extract (50 mg/kg, oral) were orally administered in group no 7 and 8 respectively.

While, two separate groups (Group no 9 and 10) of mice pretreated with dopaminergic antagonist Haloperidol ( $0.2 \mathrm{mg} / \mathrm{kg}$, IP); $45 \mathrm{~min}$ post treated by vehicle (5\% Tween 80 solution, oral) and $V$. wallichii extract $(50 \mathrm{mg} / \mathrm{kg}$, oral $)$ respectively to evaluate possible involvement of dopaminergic neurochemical in $V$. wallichii induced antidepressant effect in mice.

To assess the possible involvement of serotonergic neurochemical mechanism in $V$. wallichii induced antidepressant effects; two other separate groups (Group no 11 and 12) of mice were taken. After 45 min administration of serotonin synthesis inhibitor p-CPA (100 $\mathrm{mg} / \mathrm{kg}$, IP, 4 consecutive days, once in a d), vehicle (5\% Tween 80 solution) and $V$. wallichii extract $(50 \mathrm{mg} / \mathrm{kg})$ were orally administered in group no 11 and 12, respectively. Control and positive control groups of mice were administered only vehicle $(5 \%$ Tween 80 solution) and $V$. wallichii extract $(50 \mathrm{mg} / \mathrm{kg})$ respectively. Thirty min post treatment; all animals were tested in the forced swimming test for the evaluation of antidepressant activity.

\section{Antidepressant activity by Tail Suspension Test (TST)}

Tail Suspension Test (TST) is simple, rapid and reliable method for screening antidepressant effect in mice. It is considered for measuring mood level assay immobility time, which indicates changes in mood. TST induced immobility in animals is reduced by a large no of clinically active and atypical antidepressant effect [22]. The TST was performed in Swiss Albino Mice weighing 20-25 g according to the method [23] with slight modifications. Mice were suspended on the edge of the table $40 \mathrm{~cm}$ above the floor by adhesive tape placed approximately $2 \mathrm{~cm}$ from the tip of the tail. The total immobility time was observed for an overall period of $6 \mathrm{~min}$ as described by Steru et al. (1985) [23]. Mice were considered immobile only when they hung passively and completely motionless. Another 72 selected mice were divided into 12 different groups $(n=6)$ to evaluate the antidepressant activity in TST. In groups $1^{\text {st }}$ and $2^{\text {nd }}$, Vehicle (5\% Tween 80 , oral) and Imipramine $(15 \mathrm{mg} / \mathrm{kg}, \mathrm{IP})$ were administered for 21 successive $d$ respectively. While, in groups no $3^{\text {rd }}, 4^{\text {th }}, 5^{\text {th }}$ and $6^{\text {th }} V$. wallichii extract $(20 \%$ alcohol) at dose rate $20,50,125$ and $300 \mathrm{mg} / \mathrm{kg}$ were administered by oral route for 21 successive $d$ respectively. In groups no $7^{\text {th }}$ and $8^{\text {th }}$, Vehicle $(5 \%$ Tween 80 ) and $50 \mathrm{mg} / \mathrm{kg}$ dose of $V$. wallichii extract $(20 \%$ alcohol) were orally administered $45 \mathrm{~min}$ post treatment of adrenergic antagonist Prazosin (1 mg/kg, IP) respectively. In group no $9^{\text {thand }}$ $10^{\text {th }}$, Vehicle (5\% Tween 80 ) and $50 \mathrm{mg} / \mathrm{kg}$ dose of $V$. wallichii extract $(20 \%$ alcoholic) was orally administered $45 \mathrm{~min}$ post treatment of dopaminergic antagonist Haloperidol $(0.2 \mathrm{mg} / \mathrm{kg}, \mathrm{IP})$ respectively. In groups no $11^{\text {th }}$ and $12^{\text {th }}$, Vehicle $(5 \%$ Tween 80$)$ and $50 \mathrm{mg} / \mathrm{kg}$ dose of $V$. wallichii extract $(20 \%$ alcohol) were orally administered 45 min post treatment of serotonin synthesis inhibitor p-CPA (100 mg/kg, IP, 4 consecutive d, once in a d) respectively.

After 30 min of treatment, all animals were tested by TST for the evaluation of antidepressant activity and investigate the involvement of possible neurochemical mechanism in V. wallichii induced antidepressant effect in mice. During experiments, duration of immobility of mice was measured for next $5 \mathrm{~min}$ in TST.

\section{Locomotor activity}

To evaluate the possible effects of $V$. wallichii on locomotor activity, the mice were placed in digital photoactometer (M/S Orchid Scientifics, India). Locomotor activity was measured by the interceptions in the photobeams in the instrument. Locomotor activity of mice was recorded during the next $5 \mathrm{~min}$ of a total $7 \mathrm{~min}$ test at the end of the experiment on the last day. The locomotor activity was expressed in terms of total photobeam counts $(X+Y$ scores), 5 min per animal [24]. For locomotor activity, 36 mice were randomly divided into six different groups $(n=6)$ for the present study.

Vehicle (5\% Tween 80$)$ and Imipramine $(15 \mathrm{mg} / \mathrm{kg})$ were administered orally for 21 successive $d$ in the control group (Group no 1) and positive control group (Group no 2) respectively. $V$. wallichii was administered at four doses of 20,50, 125 and 300 $\mathrm{mg} / \mathrm{kg}$ body weight, orally for $21 \mathrm{~d}$ in four different groups (Group no $3,4,5$ and 6 ) respectively. Imipramine was taken a positive control group for comparing the locomotor activity of $V$. wallichii. Thirty min after the last administration, all animals were tested in the photoactometer for their locomotor activity.

\section{Statistical analysis}

The results of the study were expressed as mean \pm SD Statistical analysis of the results were done by using one way ANOVA followed by post-hoc analysis of Dunnett's ' $t$ ' test for all groups compared vs. control group and Student-Newman-Keuls Test for comparing all pairs of groups. ${ }^{*}$ p values $<0.05$ significant value vs. control group and \#p values $<0.05$ significant value vs. VW-50 (V. wallichii, 50 $\mathrm{mg} / \mathrm{kg}$ ) treated group.

\section{RESULTS AND DISCUSSION}

\section{Acute toxicity study}

In acute toxicity studies, no significant changes in food intake, body weight, general, physical and psychological behaviour of treated animals were observed as well as there were no signs of toxicity and mortality found in oral doses of ethanolic extract of $V$. wallichii up to $2 \mathrm{~g} / \mathrm{kg}$ body weight. Hence it may be categorized as non-toxic and safe.

\section{Effect of Imipramine and V. wallichii on immobility time of mice}

Both FST and TST tests have been used to evaluate the anti-stress, mood elevator and anti-fatigue effects of various compounds [22, 25, 26]. Both tests are quite sensitive and specific to all major classes of antidepressant drugs [22, 27]. Above induces a state of behavioral condition similar to human depression $[22,28]$. Fig. 1 and 2 depicts the effect of oral doses of ethanolic extract of $V$. wallichii $(20,50,125$ and $300 \mathrm{mg} / \mathrm{kg}$ ) and positive control drug Imipramine $(15 \mathrm{mg} / \mathrm{kg})$ on immobility time of mice in FST and TST. Reduction in immobility time of animals during a test, indicates neuromuscular anti-fatigue (skeletal muscle performance activity) and antidepressant effects in animals.

Administration of Imipramine $(15 \mathrm{mg} / \mathrm{kg})$ in mice was significantly decreased the immobility time in both tests. Similarly to Imipramine, Oral administration of different dosage (50, 125 and $300 \mathrm{mg} / \mathrm{kg}$ body wt) of $V$. wallichii for $21 \mathrm{~d}$ in mice were showed significant $(\mathrm{P}<0.05)$ decrease in immobility time in both tests, but lowest doses $(20 \mathrm{mg} / \mathrm{kg}$ ) did not exhibit in FST as compared to control group. $V$. wallichii at the dosage 20,50,125 and $300 \mathrm{mg} / \mathrm{kg}$ in mice showed decreased immobility time a dose related graded manner in the FST and TST in mice, whereas the effect at the highest dose $(300 \mathrm{mg} / \mathrm{kg})$ 
exhibit decreased immobility time but did not in a dose related graded manner in FST. Hence, $V$. wallichii at the dosage 20, 50, 125 and $300 \mathrm{mg} / \mathrm{kg}$ in mice showed dose dependent manner decrements the immobility time in both tests. Similarly, Subhan et al. (2010) [29] has reported that fluoxetine as well as methanolic and aqueous extracts of $V$. wallichii induced monophasic dose-related decrements in immobility times in FST and TST tests. While, the aqueousethanolic fraction induced a biphasic dose-response profile since it produced a graded effect up to $200 \mathrm{mg} / \mathrm{kg}$ but the highest dose (250 $\mathrm{mg} / \mathrm{kg}$ ) was inactive in the FST. The results of the present study revealed that oral administration of ethanolic extract of $V$. wallichii (50, 125 and $300 \mathrm{mg} / \mathrm{kg}$ body weight) significantly $(\mathrm{P}<0.05)$ enhances neuromuscular endurance and antidepressant effects in mice. Ahmad et al. (1998) [30] have reported that a gem-containing Unani formulation with $V$. wallichii has anti-stress activity against the physical stress of forced swimming. The present study is also well supported by Subhan et al. (2009) [14] who have reported that terpenoid content of $V$. wallichii extracts has antidepressant response. Hence, from the study it concluded that $V$. wallichii extracts have antidepressant effects in mice.

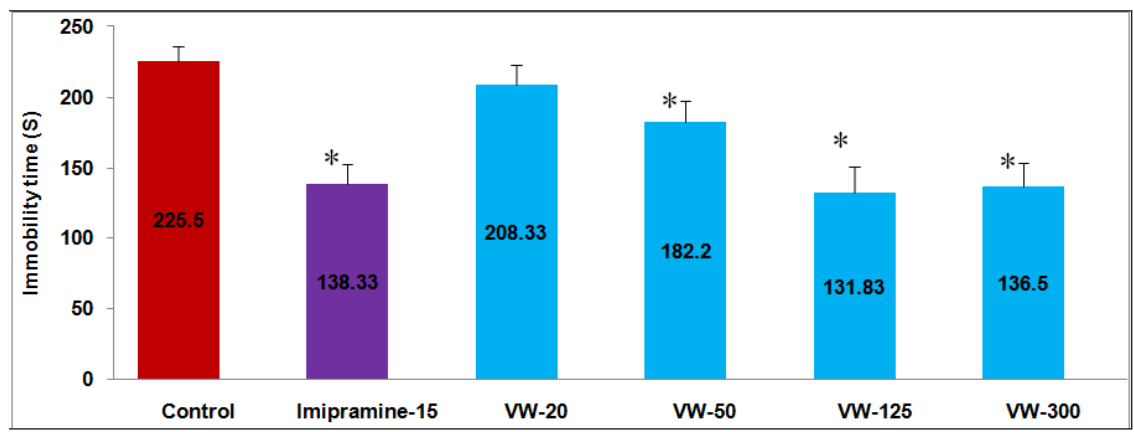

Fig. 1: Effect of $V$. wallichii and Imipramine on immobility time of mice in FST, [Values expressed in time (s) as mean \pm SD from six animals in each group at respective time-points. VW-20, VW-50, VW-125, and VW-300: Valeriana wallichii (20, 50, 125 and 300 mg/kg body wt.)]

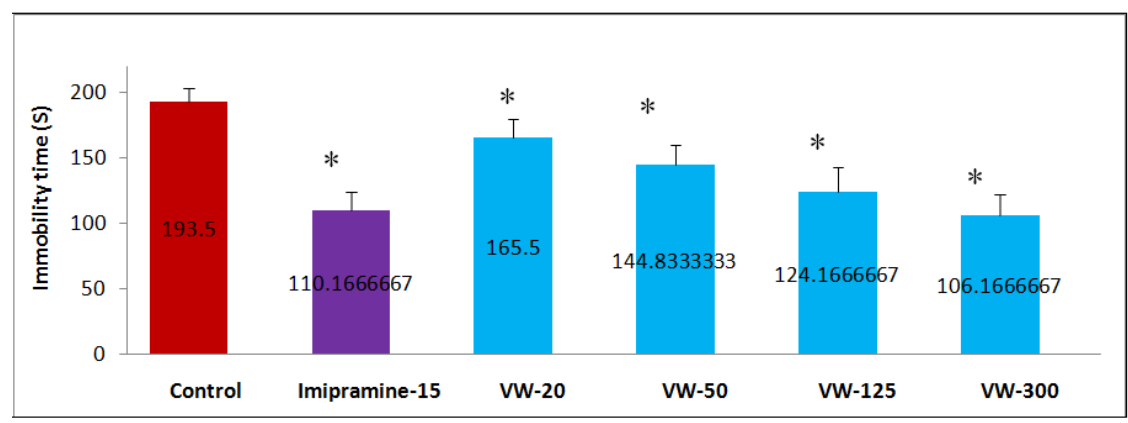

Fig. 2: Effect of $V$. wallichii and Imipramine on immobility time of mice in TST, [Values expressed in time (s) as mean \pm SD from six animals in each group at respective time-points. VW-20, VW-50, VW-125, and VW-300: Valeriana wallichii (20, 50, 125 and 300 mg/kg body wt.)]

Effect of prazosin on $V$. wallichii induced reduction in immobility time of mice

Etiology of depression is well known that abnormalities of noradrenergic, GAB Aergic, dopaminergic and serotonergic transmission are known to play a key role in the depression. Monoamine neurotransmitters like serotonin, dopamine, norepinephrine and epinephrine in the central nerve system have had important roles in the regulation of mood, emotion, cognition, fatigue etc. In the study, we aimed was investigated the association of neurochemical mechanism with antidepressant effects of $V$. wallichii in mice. Fig. 3 and 4 depicts the effect of alpha- 1 adrenergic antagonist prazosin (1 mg/kg, IP) alone and in combination with aqueous alcoholic extract of $V$. wallichii $(50 \mathrm{mg} / \mathrm{kg})$ on immobility time in mice during FST and TST tests.

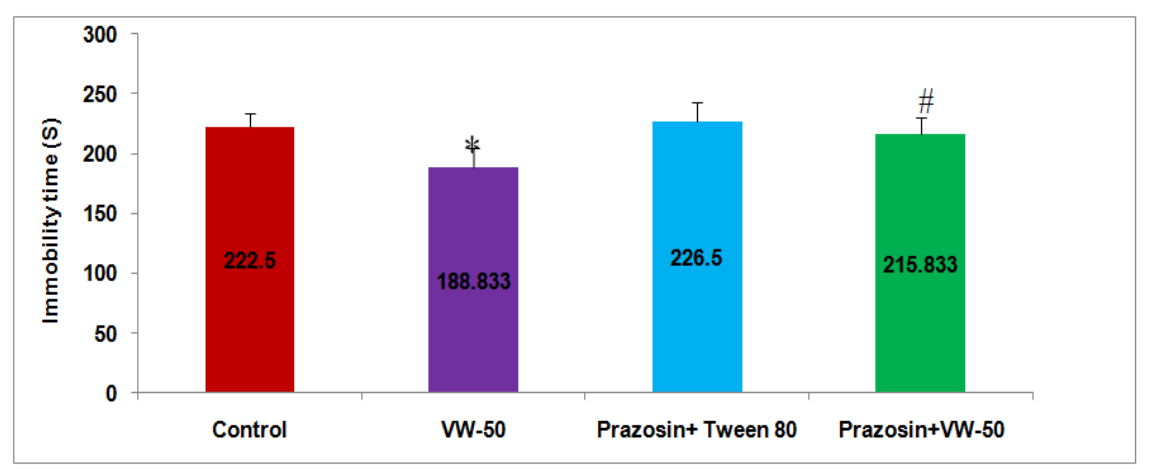

Fig. 3: Effect of prazosin on $\mathrm{V}$. wallichii induced reduction in immobility time in FST, [Values expressed in time (s) as mean \pm SD from six animals in each group at respective time-points. VW-50: Valeriana wallichii (50 mg/kg body wt.)] 


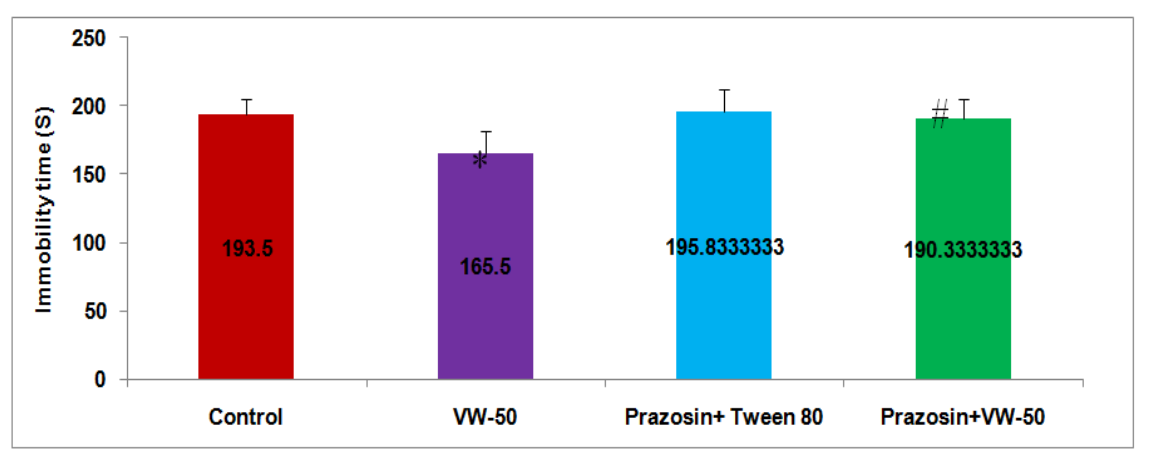

Fig. 4: Effect of prazosin on $V$. wallichii induced reduction in immobility time in TST, [Values expressed in time (s) as mean \pm SD from six animals in each group at respective time-points. VW-50: Valeriana wallichii ( $50 \mathrm{mg} / \mathrm{kg}$ body wt.)]

Prazosin is sympatholytic drug which acts as alpha- 1 adrenergic neuron antagonist (inverse agonist) and it is used to treat high blood pressure, anxiety, stress disorder etc. Administration of aqueous alcoholic extract of $V$. wallichii $(50 \mathrm{mg} / \mathrm{kg})$ in mice were showed significant $(\mathrm{P}<0.05)$ decrease in immobility time as compared to control group. Whereas, V. wallichii $(50 \mathrm{mg} / \mathrm{kg})$ induced reduction in immobility time in mice was significantly prevented by pretreatment of alpha-1 adrenergic antagonist Prazosin $(1 \mathrm{mg} / \mathrm{kg}$, IP) in FST. Similar to FST test, $V$. wallichii $(50 \mathrm{mg} / \mathrm{kg}$ ) induced reduction in immobility time in mice was significantly prevented by pretreatment of alpha- 1 adrenergic antagonist Prazosin $(1 \mathrm{mg} / \mathrm{kg}$, IP) in TST test. While, alone treatment of Prazosin $(1 \mathrm{mg} / \mathrm{kg}$, IP) did not show significant change in immobility time in mice in both FST and TST tests. Similarly, Sah et al. (2011) [31] have reported that prolong the treatment of $V$. wallichii significantly increases the levels of norepinephrine in forebrain of a mouse. He has also reported that the antidepressant effect of essential oil $(20 \mathrm{mg} / \mathrm{kg})$ of $V$. wallichii was prevented by pretreatment of mice with l-arginine $(750 \mathrm{mg} / \mathrm{kg}$ IP) and sildenafil (5 mg/kg IP) [31]. Hence, the present study revealed that $V$. wallichii induced anti-fatigue and antidepressant effects in mice is significant $(\mathrm{P}<0.05)$ blocked when pretreated with an alpha-1 adrenergic antagonist Prazosin in TST and FST tests. However, it reveals from the study that the adrenergic neuronal system may have involved in the $V$. wallichii induced anti-fatigue and antidepressant effect in mice.

Effect of haloperidol on $V$. wallichii induced reduction in immobility time of mice

Fig. 5 and 6 depicts the effect of dopaminergic antagonist Haloperidol $(0.2 \mathrm{mg} / \mathrm{kg}$, IP) alone and in combination with aqueous alcoholic extract of $V$. wallichii $(50 \mathrm{mg} / \mathrm{kg})$ on immobility time of mice in the FST and TST.

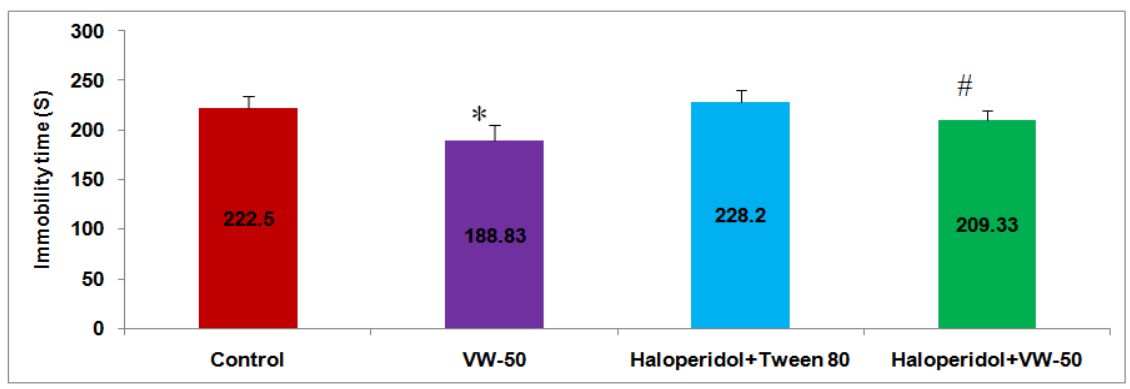

Fig. 5: Effect of haloperidol on $V$. wallichii induced reduction in immobility time in FST, [Values expressed in time (s) as mean \pm SD from six animals in each group at respective time-points. VW-50: Valeriana wallichii (50 $\mathrm{mg} / \mathrm{kg}$ body wt.)]

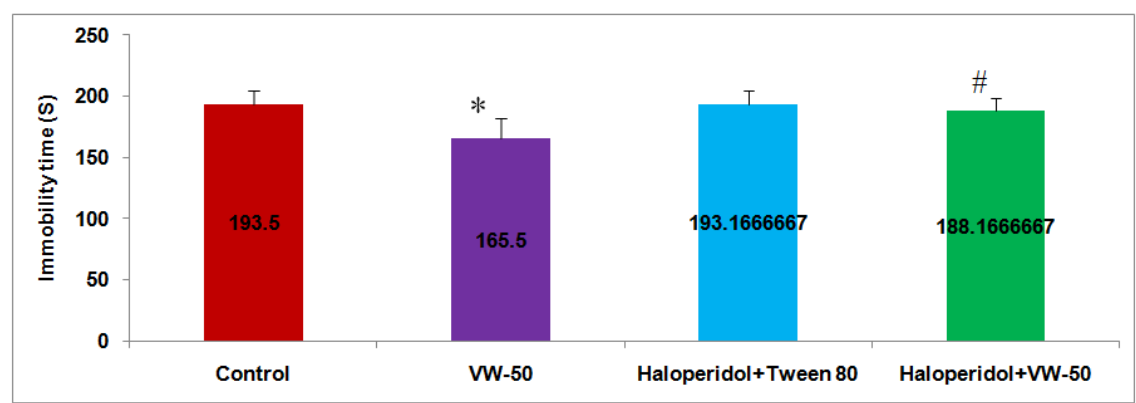

Fig. 6: Effect of haloperidol on $V$. wallichii induced reduction in immobility time in TST, [Values expressed in time (s) as mean \pm SD from six animals in each group at respective time-points. VW-50: Valeriana wallichii ( $50 \mathrm{mg} / \mathrm{kg}$ body wt.)]

Haloperidol is a typical antipsychotic drug which acts as nonselective D-2 dopamine receptor antagonist and it is used to treat schizophrenia, mania, psychosis etc. disorders. In FST and TST tests, $V$. wallichii $(50 \mathrm{mg} / \mathrm{kg})$ induced decrements in immobility time of mice was significantly prevented by pretreatment of D-2 dopamine non selective receptor antagonistic Haloperidol $(0.2 \mathrm{mg} / \mathrm{kg}$, IP).
Whereas, alone treatment of Haloperidol $(0.2 \mathrm{mg} / \mathrm{kg}$, IP) did not show significant change in immobility time in above both tests. Hence, the findings of the present study revealed that $V$. wallichii induced reduction in immobility time was significantly $(\mathrm{P}<0.05)$ blocked by pretreatment of a D-2 dopamine receptor antagonistic Haloperidol. Our study is supported by Sah et al., (2011) [31] who 
have reported that prolong the treatment of $V$. wallichii significantly increase the levels of dopamine in forebrain of mouse. Hence, the present study revealed that $V$. wallichii induced anti-fatigue and antidepressant effects in mice are significant $(\mathrm{P}<0.05)$ blocked when pretreated with a Haloperidol. However, in the present study concluded that the dopaminergic neuronal system may have interaction in $V$. wallichii induced anti-fatigue and antidepressant effects in mice.
Effect of p-CPA on $V$. wallichii induced reduction in immobility time of mice

Fig. 7 and 8 depicts the effect of p-CPA $(100 \mathrm{mg} / \mathrm{kg}, \mathrm{IP}, 4$ consecutive days) alone and in combination with ethanolic extract of $V$. wallichii $(50 \mathrm{mg} / \mathrm{kg})$ on immobility time of mice in the FST and TST.

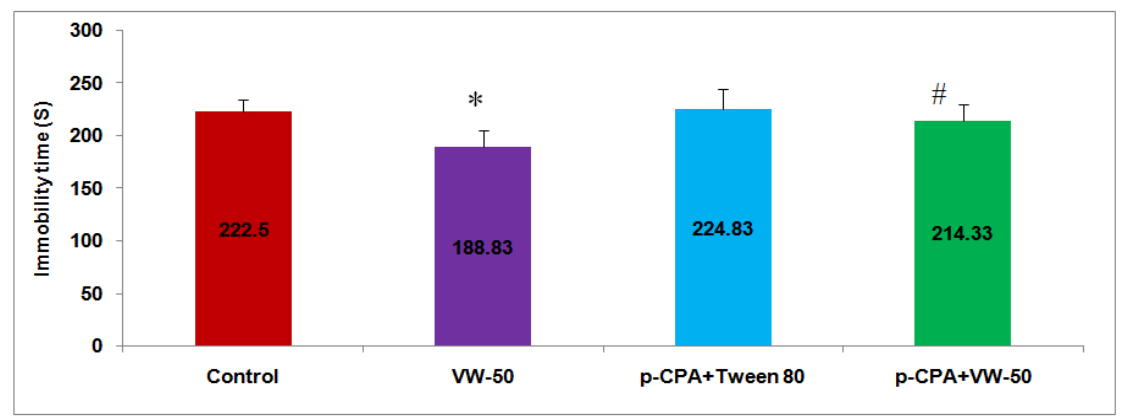

Fig. 7: Effect of p-CPA on $V$. wallichii induced reduction in immobility time in FST, [Values expressed in time (s) as mean \pm SD from six animals in each group at respective time-points. VW-50: Valeriana wallichii ( $50 \mathrm{mg} / \mathrm{kg}$ body wt.)]

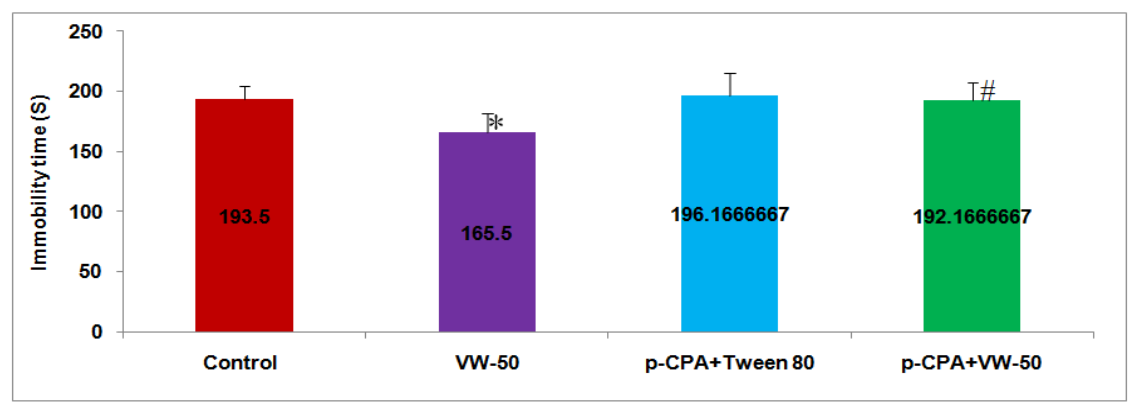

Fig. 8: Effect of p-CPA on V. wallichii induced reduction in immobility time in TST, [Values expressed in time (s) as mean \pm SD from six animals in each group at respective time-points. VW-50: Valeriana wallichii ( $50 \mathrm{mg} / \mathrm{kg}$ body wt.)]

p-CPA acts as irreversible and selective inhibitor of tryptophan hydroxylase enzymes, which is a rate limiting factor for biosynthesis of serotonin. V. wallichii $(50 \mathrm{mg} / \mathrm{kg})$ induced reduction in immobility time was significantly prevented by pretreatment of p-CPA $(100 \mathrm{mg} / \mathrm{kg}$, IP, 4 consecutive days) in FST. Similar to FST test, $V$. wallichii $(50 \mathrm{mg} / \mathrm{kg})$ induced reduction in immobility time was significantly blocked by pretreatment of p-CPA ( $100 \mathrm{mg} / \mathrm{kg}$, IP, 4 consecutive d) in TST test also. While, alone treatment of p-CPA $(100 \mathrm{mg} / \mathrm{kg}$, IP) did not show significant change in immobility time in FST and TST tests. Hence, the findings of the present study revealed that the effect of $V$. wallichii on reduction in immobility time was significantly $(\mathrm{P}<0.05)$ blocked by pretreatment of a serotonin synthesis inhibitor p-CPA in mice.

According to the results of the present study, $V$. wallichii has induced anti-fatigue and antidepressant effects in mice were prevented by

\begin{abstract}
the pretreatment of alpha-1 adrenergic antagonist Prazosin, nonselective dopaminergic antagonist Haloperidol and serotonin synthesis inhibitor p-CPA in both FST and TST tests, which is indicative of involvement of adrenergic, dopaminergic and serotonergic systems in the enhancement of neuronal anti-fatigue and antidepressant effect of $V$. wallichii in mice. Hence, the results suggested that $V$. wallichii enhanced neuronal anti-fatigue and antidepressant effects through adrenergic, dopaminergic and serotonergic system.
\end{abstract}

\section{Effect of V. wallichii and Imipramine on locomotor activity}

Fig. 9 depicts the effect of ethanolic extract of $V$. wallichii $(20,50$ 125 and $300 \mathrm{mg} / \mathrm{kg}$ ) and positive control drug Imipramine (15 $\mathrm{mg} / \mathrm{kg}$ ) on locomotor activity of mice in photoactometer.

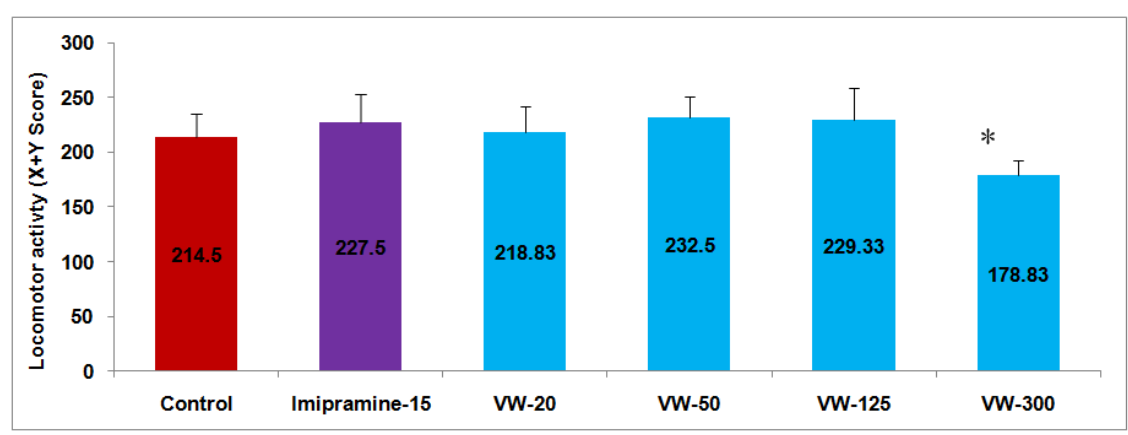

Fig. 9: Effect of $V$. wallichii and Imipramine on locomotor activity in actophotometer, [Values expressed in scores as mean \pm SD from six animals in each group at respective time-points. VW: Valeriana wallichii] Locomotor activity (X+Y scores) of each mouse were measured 30 min post injection time-period 
In the experiment, locomotor activity of Imipramine treated animals was not significantly affected as compared to control animals. Similar to Imipramine, 20, 50 and $125 \mathrm{mg} / \mathrm{kg}$ dosage of $V$. wallichii did not alter the locomotor activity of mice significantly. Whereas, higher dose of $V$. wallichii (300 mg/kg body weight, orally) significantly $(\mathrm{P}<0.05)$ decreased locomotor activity as compared to control and positive control (Imipramine) groups. Hence, this study reveals that Imipramine and $V$. wallichii has no effect on locomotor activity but higher dose of $V$. wallichii $(300 \mathrm{mg} / \mathrm{kg}$ body wt.) has a significant effect in decreasing the locomotor activity, similar to Subhan et al. (2010) [29] they have exhibited that the highest doses of aqueous-ethanolic extract reduced locomotor activity. However, $V$. wallichii does not interfere the motor activity of mice at lower doses; while higher doses may produce other effects-like sedative or sleep enhancing in mice. One another researcher has also reported that the presence of sedative and sleep-enhancing compound flavanone glycoside 2S (-) hesperidin (HN) in V. officinalis and $V$. wallichii [9]. Thus, it may be concluded that the higher doses of $V$. wallichii may have sedative or sleep-enhancing-like effect in mice.

\section{CONCLUSION}

Oral administration of $V$. wallichii at dosage rate $(50-300 \mathrm{mg} / \mathrm{kg}$ body weight) showed significant $(\mathrm{P}<0.05)$ enhancement in neuronal anti-fatigue, mood elevator and antidepressant effects in mice without interfering their motor activity. While, pretreated animals with Prazosin alpha 1-adrenoreceptor antagonist, Haloperidol as nonselective D-2 dopaminergic antagonist and p-CPA as serotonin synthesis inhibitor did not show significant $(\mathrm{P}<0.05)$ enhancement in $V$. wallichii induced anti-fatigue, mood modifying and antidepressant effects. Hence, it is concluded that the neuronal antifatigue, mood elevator, and antidepressant effects of $V$. wallichii may be mediated via adrenergic, dopaminergic and serotonergic systems. No significant difference was noticed in the locomotor activity of mice, which were administered with Imipramine $(15 \mathrm{mg} / \mathrm{kg})$ and $V$. wallichii $(20,50$, and $125 \mathrm{mg} / \mathrm{kg})$. While, V. wallichii at the higher dose $(300 \mathrm{mg} / \mathrm{kg})$ exhibited significant $(\mathrm{P}<0.05)$ reduction in locomotor activity, which may be attributed to sedative or sleep enhancing-like effect in mice. Therefore, there is scope of more research on the effect of $V$. wallichii and involvement of specific parts of brain and receptor.

\section{ACKNOWLEDGEMENT}

Authors are thankful to Col DM Prasad, Officer In-Charge, DIBER, Field Station, Pithoragarh for their valuable suggestions during the study. Authors are also thankful to Dr. HK Pandey, Scientist ' $F$ ' for their valuable support during the study.

\section{FUNDING}

This article was supported by itself Defence Institute of Bio-Energy Research (DIBER), DRDO.

\section{AUTHORS CONTRIBUTIONS}

Harsahay Meena: Study design, conduct experiments, data collection and analysis, and preparing manuscript. Col. V K Joshi: The manuscript was reviewed and edited. The experiment was conducted under the guidance and supervision of Dr Madhu Bala, Scientist ' $G$ '.

\section{CONFLICTS OF INTERESTS}

No conflicts of interest

\section{REFERENCES}

1. Nadkarni KM. Indian materia medica. $3^{\text {rd }}$ ed. Bombay, Popular Prakashan; 1976. p. 260.

2. Sharma PV. Priya Nighuntu. $1^{\text {st }}$ ed. Varanasi, Chaukhambha Surabharati Prakasan; 2001. p. 60.

3. Becker H, Chavadej S. Valepotriates: production by plant cell cultures. In biotechnology in agriculture and forestry, edited by Bajaj YPS. Medicinal and Aromatic Plants. Berlin Springer Verlag 1988;4:294-309.

4. Said HM. Hamdard pharmacopoeia of eastern medicine. Karachi, Times Press; 1970.
5. Marder M, Viola H, Wasowski C, Fernandez S, Medina JH, Paladini AC. 6-methylapigenin and hesperidin: new Valeriana flavonoids with activity on the CNS. Pharmacol Biochem Behav 2003;75:537-45.

6. Sharma R. Medicinal plants of India. In: An encyclopedia. New Delhi, Daya Publishing House; 2003.

7. Gilani $\mathrm{AH}$, Khan AU, Jabeen $\mathrm{Q}$, Subhan $\mathrm{F}$, Ghafar R. Antispasmodic, and blood pressure lowering effects of Valeriana wallichii are mediated through $\mathrm{K}+$ channel activation. J Ethnopharmacol 2005;100:347-52.

8. Rao SN, Mittal S, Menghani E. Evaluation of antioxidant properties of Valeriana Wallichi to scavenge free radicals. Asian J Pharm Clin Res 2012;5:238-40.

9. Fernandez S, Wasowski C, Paladini AC, Marder M. Sedative and sleep-enhancing properties of linarin, a flavonoid-isolated from Valeriana officinalis. Pharmacol Biochem Behav 2004;77:399-404.

10. Bhattacharyya D, Jana U, Debnath PK, Suri TK. Initial exploratory observational pharmacology of Valeriana wallichii on stress management: a clinical report. Nepal Medical College J 2007;9:36-9.

11. Rehni AK, Pantlya HS, Shri R, Singh M. Effect of chlorophyll and aqueous extracts of Bacopa monniera and Valeriana wallichii on ischemia and reperfusion induced cerebral injury in mice. Ind J Exp Biol 2007;45:764-9.

12. Shalam M, Shantakumar SM, Narasu ML. Pharmacological, and biochemical evidence for the antidepressant effect of the herbal preparation Trans-01. Ind J Pharmacol 2007;39:231-4.

13. Nandhini S, Narayan KB, Ilango K. Valeriana officinalis: a review of its traditional uses, phytochemistry and pharmacology. Asian J Pharm Clin Res 2018;11:36-41.

14. Subhan F, Karim N, Gilani AH, Sewell RDE. Terpenoid content of Valeriana wallichii extracts and antidepressant-like response profiles. Phytother Res 2009;24:686-91.

15. Thies PW. Linarin-isovalerianate, a currently unknown flavonoid from Valeriana wallichii. Planta Med 1968;16:363-71.

16. Bounthanh C, Bergmann C, Beck JP, Hagg Berrurier M, Anton R. Valpotriates, a new class of cytotoxic and antitumor agents. Planta Med 1981;41:21-8.

17. Willis RB, Bone $K$, Morgan M. Herbal products: active constituents, mode of action and quality control. Nutr Res Rev 2000;13:47-77.

18. Organization for Economic Cooperation and Development (OECD) Guidelines for Testing of Chemicals. Guidelines 423, Acute Oral Toxicity-Acute Toxic Class Method; 1996.

19. Porsolt RD, Bertin A, Jalfre M. Behaviour despair in mice: a primary screening test for antidepressant. Archives Internationes De Pharmacodynamie Et De Therapie 1977;229:327-36.

20. Brocardo PS, Budni J, Lobato KR, Kaster MP, Rodrigues AL. Antidepressant like effect of folic acid: involvement of NMDA receptors and L-arginine-nitric oxide-cyclic guanosine monophosphate pathway. Eur J Pharmacol 2008;598:37-42.

21. Rosa AO, Kaster MP, Binfare RW, Morales S, Martin Aparicio E, Navarro Rico ML et al. Antidepressant-like effect of the novel thiadiazolidinone NP031115 in mice. Progr Neuropsychopharmacol Biol Psychiatry 2008;32:1549-56.

22. Wesołowska A, Nikiforuk A, Stachowicz K, Tatarczyńska E. Effect of the selective 5-HT7 receptor antagonist SB 269970 in animal models of anxiety and depression. Neuropharmacology 2006;51:578-86.

23. Steru L, Chermat R, Thierry B, Simon P. The tail suspension test: a new method for screening antidepressants in mice. Psychopharmacol 1985;85:367-70.

24. Reddy DS, Kaur G, Kulkarni SK. Sigma (sigma1) receptor mediated antidepressant-like effects of neurosteroids in the porsolt swim test. Neuroreports 1998;9:3069-73.

25. Koh JH, Kim KM, Kim JM, Song JC, Suh HJ. Antifatigue and antistress effect of the hot-water fraction from mycelia of Cordyceps sinensis. Biol Pharmacol Bull 2003;26:691-4.

26. Nozawa Y, Yamada K, Okabe Y, Ishizaki T, Kuroda M. The antifatigue effects of the low-molecular-weight fraction of bonito extract in mice. Biol Pharmacol Bull 2009;32:468-74.

27. Detke MJ, Rickels M, Lucki I. Active behavior in the rat forced swimming test differentially produced by serotonergic and 
noradrenergic antidepressant. Psychopharmacology 1995;121: 66-72.

28. Whillner P. The validity of animal model of depression Psychopharmacology 1984;83:1-16.

29. Subhan F, Karim N, Gilani AH, Sewell RD. Terpenoid content of Valeriana wallichii extracts and antidepressant-like response profiles. Phytother Res 2010;24:686-91.
30. Ahmad G, Amin KM, Khan NA, Tajuddin M. The anti-stress activity of a gem-containing Unani formulation against diverse stressors. J Ethnopharmacol 1998;59:187-93.

31. Sah SP, Mathela CS, Chopra K. Antidepressant effect of Valeriana wallichii patchouli alcohol chemotype in mice: behavioural and biochemical evidence. J Ethnopharmacol 2011;135:197-200. 